\title{
Assessment of Heterogeneity in the Development and Use of Land Resources in the Central Chernozem Macroregion
}

\author{
Marina Vladyka \\ Department of Applied Economics and Economic Security \\ Belgorod State National Research University \\ Belgorod, Russia \\ vladyka@bsu.edu.ru \\ Elena Gorbunova \\ Department of Economic Innovation and Finance \\ Belgorod State National Research University \\ Belgorod, Russia \\ gorbunova_e@bsu.edu.ru
}

\author{
Tatyana Goncharenko \\ Department of Economic Innovation and Finance \\ Belgorod State National Research University \\ Belgorod, Russia \\ goncharenko@bsu.edu.ru
}

Denis Solntsev

Department of Applied Economics and Economic Security Belgorod State National Research University

Belgorod, Russia

$503501 @$ bsu.edu.ru

\begin{abstract}
The formation and development of land relations in Russia at the level of macroregions takes place with the adaptation of new trends in spatial development and is largely based on taking into account factors that affect the results of the use of natural resources. However, in modern conditions, the issues of improving the efficiency of the use of limited land resources require special attention to the regulation of land relations in the management system of the agroindustrial complex. This is due to the complexity of the problems of land ownership, land use and land use. Targeted effective use of land resources - this is the main direction of regulation on the part of federal and regional authorities, which activates the activity on land delimitation throughout the Central Chernozem macroregion. The area of agricultural land in the Central Chernozem macroregion increased by 5.1 thousand hectares $(0.4 \%)$ from 2015 to 2018 . Directions of use of land resources determine the structure of the land fund. It can be noted that in the total land fund of the Central Chernozem macroregion, the share of agricultural land reaches $79.6 \%$. This indicator is significantly higher than the level of the Russian Federation as a whole (12.3\%). In the Central Federal District, this figure is $51.6 \%$. While there is a General trend in reduction of agricultural land, which is associated with the expansion of industrial enterprises, individual housing construction in the settlements, the establishment and organization of protected areas. The structure of the land fund of the regions differs significantly by the categories of available land. It is the land that creates the basis for human activity, meeting the various needs and interests of the individual and society as a whole. The observed changes in the agricultural sector requires effective land resources, which allows to increase the effectiveness of the system of interbudgetary relations, as have a direct influence on the spatial development of the region, and remain one of the main vectors of its practical implementation. In addition, the formation of a system of social protection of the population will be more effective if the state's support is provided through targeted channels. This will make it possible to activate the labor and economic functions of self-regulation of the financial situation of households in the changing socio-economic
\end{abstract}

situation. The article contains the initial stage of the study devoted to the assessment of the heterogeneity of the development and use of land resources in the Central Chernozem macroregion.

Keywords-limited land resources, problems of land ownership and land use, legal support for the development of land relations, assessment of heterogeneity in the use of land resources.

\section{INTRODUCTION}

Modern experience in ensuring the main directions of socio-economic development of the country, taking into account the spatial characteristics of macroregions, indicates the need for state intervention in the use of land resources.

The current system of land relations makes it necessary to find new ways to improve the efficiency and competitiveness of the use of natural resources. Analysis of the state of functioning of land relations in the agricultural sector of the Russian Federation shows that they have undergone radical changes in recent years due to the difficult socio-economic situation in the country. It is important for our research that the current trends have led to the transformation of the land market and its main segments, changes in the forms and types of land ownership, the size and structure of land ownership and land use, as well as the fertility of agricultural land.

\section{METHODS}

Research Methods include a set of General scientific methods such as induction, deduction, synthesis and analysis, as well as special methods such as adaptive approach, regression analysis.

\section{MAIN PART}

Each subject of the Russian Federation has its own characteristics and promising socio-economic specializations. The Central Chernozem macroregion is one of the most 
developed and densely populated subjects of the territorial division of the Russian Federation. Its features are that it is the largest iron ore base and a high degree of agricultural development as agrarian-industrial territory traditionally rich in fertile soils predominate throughout. In addition, this macroregion is rich in natural resources: iron, titanium and copper-Nickel ores; bauxite; phosphorites; refractory clays; natural building materials (stone, crushed stone, sand). According to the main indicators of the development of the Central Chernozem macroregion, it is possible to distinguish it quite successfully, which is confirmed by the production indices shown in figure 1.

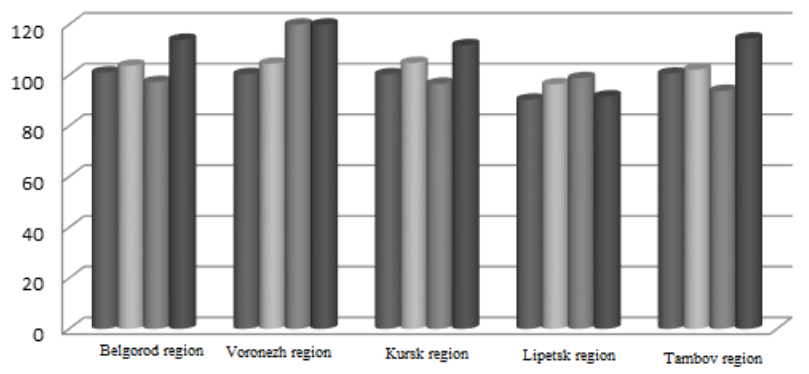

- Extraction of mineral

Wrovision of electricity, gas and steam, air conditioning

- Water supply, sanitation, organization of waste collection and disposal, etc.

Fig. 1. Dynamics of production indices of the Central Chernozem macroregion by type of activity in $2019, \%$ [3]

According to the data presented in figure 1, the Voronezh region occupies a leading position in terms of mineral extraction and the results of manufacturing operations. In terms of mineral extraction, the Belgorod region ranks second in terms of these indicators and is one of the industrial and agricultural regions of the Russian Federation. Describing the Central Chernozem region, we can distinguish the Western and Eastern subdistricts that have different branches of specialization in industry. The first includes the Kursk and Belgorod regions that specialize in ferrous metallurgy, Metalworking, mining and light industry. But all regions are characterized by the development of agricultural complexes and crop and livestock production is at a high level. In the Belgorod, Voronezh and Tambov regions, animal husbandry is more developed, while in the Kursk region, crop production is more developed. Active development of agriculture is predetermined by the fact that more than $80 \%$ of the land here is fertile Chernozem (Fig. 2).

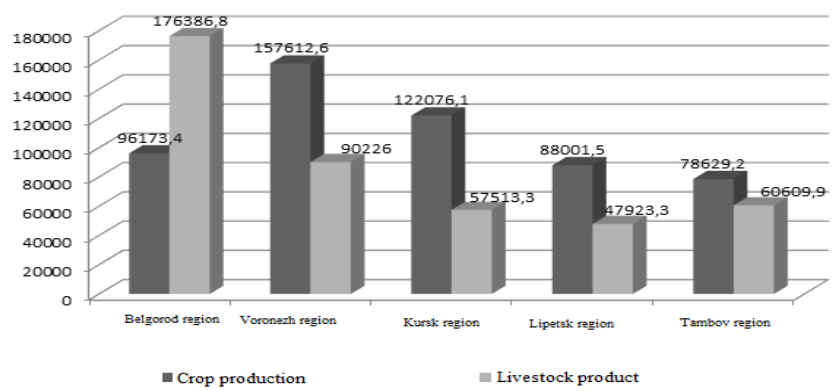

Fig. 2. Crop production and livestock production of the Central black earth macroregion in 2019, million rubles [3]

According to the data presented in figure 2, the Belgorod region occupies a leading position in animal husbandry -
176386.8 million rubles, the second place was taken by the Voronezh region - 90226.0 million rubles and the third-by the Tambov region -60609.9 million rubles. In terms of crop production in 2019 , the leading position was taken by the Voronezh region, which accounted for 157612.6 million rubles. It is possible to analyze the load on factors of production based on the current tax system in Russia, the current structure of production potential and the impact on the country's economy as a whole. The Central Chernozem macroregion is one of the largest agricultural regions in the Siberian Federal district and the Russian Federation. Its agroindustrial complex not only fully meets the needs of the population of the region in the main types of agricultural products and food, but also provides food security for other territories of the country (Fig. 3).

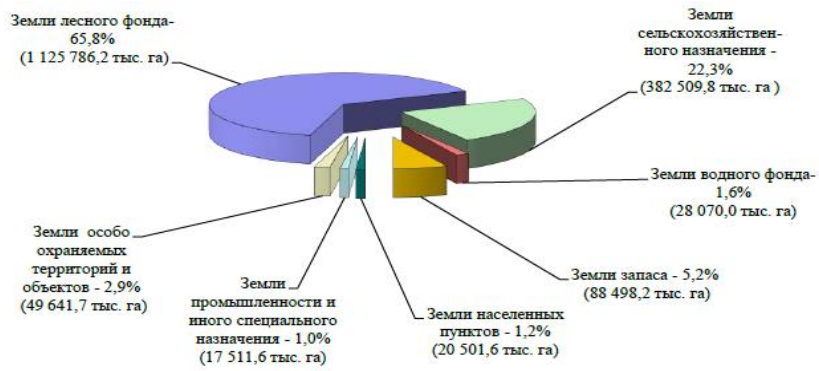

Fig. 3. Structure of the land Fund of the Russian Federation by land category as of 01.01 .2019

Legal regulation of land relations arising in connection with the transfer of land or land plots within such lands from one category to another was carried out in accordance with the Land code of the Russian Federation, Federal law No. 172-FZ of 21.12.2004 "on the transfer of land or land plots from one category to another", laws and other regulatory legal acts of the subjects of the Russian Federation. During the period under review, the transfer of land from one category mainly affected agricultural land (table 1).

TABLE I. DISTRIBUTION OF THE LAND FUND OF THE RUSSIAN FEDERATION BY LAND CATEGORIES, THOUSAND HA $[6$, p. 8]

\begin{tabular}{|c|c|c|c|c|c|}
\hline № & $\begin{array}{l}\text { The name of the } \\
\text { land categories }\end{array}$ & 01.01.2019 & 01.01.2020 & $\begin{array}{c}2019 \text { to } \\
2018 \\
(+/-)\end{array}$ & $\begin{array}{c}\text { Changes, } \\
\%\end{array}$ \\
\hline 1 & Agricultural land & 382509,8 & 381673,0 & $-836,8$ & $-0,22$ \\
\hline 2 & $\begin{array}{l}\text { Land of } \\
\text { localities, } \\
\text { including: }\end{array}$ & 20501,6 & 20551,7 & 50,1 & 0,24 \\
\hline 2.1 & $\begin{array}{l}\text { urban } \\
\text { settlements }\end{array}$ & 8403,4 & 8412,7 & 9,3 & 0,11 \\
\hline 2.2 & rural settlement & 12098,2 & 12139,0 & 40,8 & 0,34 \\
\hline 3 & $\begin{array}{l}\text { Industrial and } \\
\text { other special } \\
\text { purpose land }\end{array}$ & 17511,6 & 17614,8 & 103,2 & 0,59 \\
\hline 4 & $\begin{array}{l}\text { Lands of } \\
\text { specially } \\
\text { protected } \\
\text { territories and } \\
\text { objects }\end{array}$ & 49641,7 & 49646,4 & 4,7 & 0,01 \\
\hline 5 & $\begin{array}{l}\text { The lands of the } \\
\text { forest Fund }\end{array}$ & $\begin{array}{l}1125 \\
786,2\end{array}$ & $\begin{array}{l}1126 \\
643,0\end{array}$ & 856,8 & 0,088 \\
\hline 6 & $\begin{array}{l}\text { Lands of water } \\
\text { Fund }\end{array}$ & 28070,0 & 28069,4 & $-0,6$ & 0 \\
\hline 7 & Reserve lands & 88498,2 & 88320,8 & $-177,4$ & $-0,20$ \\
\hline \multicolumn{2}{|c|}{$\begin{array}{l}\text { Total land in the } \\
\text { Russian Federation }\end{array}$} & $\begin{array}{l}1712 \\
519,1\end{array}$ & $\begin{array}{l}1712 \\
519,1\end{array}$ & - & - \\
\hline
\end{tabular}


In the structure of agricultural land, the area of arable land was 122,689. 1 thousand hectares, deposits-4 930,4 thousand hectares, perennial plantings - 1,920,0 thousand hectares, haymaking-24,017. 2 thousand hectares, pastures-68,398. 3 thousand hectares (Fig. 4).

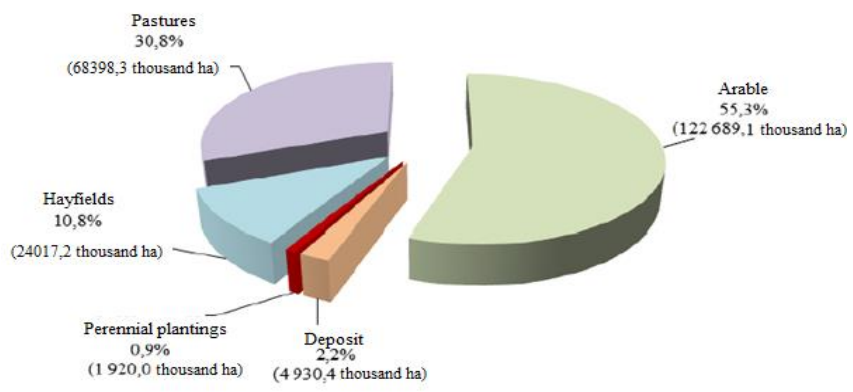

Fig. 4. Structure of agricultural land in the Russian Federation as of 01.01 .2020

The results of statistical observations for 2019 show a decrease in the area of land occupied by agricultural land, for the year it amounted to 22.1 thousand hectares. the Decrease in the area of land occupied by agricultural land was observed in 25 subjects of the Russian Federation. The greatest reduction of these lands are marked in the Kemerovo region and Ryazan region (2.3 hectares), the Republic of Tatarstan (2.0 ha), Tyumen (1.9 ha), Orenburg (1.5 thousand hectares) regions, the Republic of Bashkortostan (1.2 thousand hectares), Sverdlovsk region (by 1.0 thousand ha), Krasnodar and Altai territories, Rostov region, the Republic of Khakassia (by 0.7 thousand ha in each of the named subjects of the Russian Federation) [8, p. 31]. The General characteristics of agricultural land use are shown in table 2.

TABLE II. USE OF AGRICULTURAL LAND BY ORGANIZATIONS, THOUSAND HA

\begin{tabular}{|c|c|c|c|c|c|c|}
\hline \multirow{2}{*}{$\begin{array}{c}\text { Name of } \\
\text { economic } \\
\text { entities that } \\
\text { use land }\end{array}$} & \multirow{2}{*}{ In Total } & \multicolumn{5}{|c|}{ Agricultural land } \\
\cline { 3 - 7 } & & Arable & Deposit & $\begin{array}{c}\text { Perennial } \\
\text { Plantings }\end{array}$ & Hayfields & Pastures \\
\hline $\begin{array}{c}\text { Business } \\
\text { partnerships } \\
\text { and } \\
\text { companies }\end{array}$ & 62503,0 & 44430,2 & 1016,8 & 230,7 & 4493,8 & 12331,5 \\
\hline $\begin{array}{c}\text { Production } \\
\text { cooperative }\end{array}$ & 39428,8 & 22395,2 & 986,6 & 72,7 & 3802,8 & 12171,5 \\
\hline $\begin{array}{c}\text { State and } \\
\text { municipal } \\
\text { unitary } \\
\text { agricultural } \\
\text { enterprises }\end{array}$ & 5448,0 & 2413,5 & 73,3 & 41,1 & 551,6 & 2368,5 \\
\hline $\begin{array}{c}\text { Research } \\
\text { and } \\
\text { educational } \\
\text { institutions } \\
\text { and } \\
\text { institutions }\end{array}$ & 1627,9 & 1242,7 & 18,5 & 13,6 & 105,2 & 247,9 \\
\hline $\begin{array}{c}\text { Subsidiary } \\
\text { plot }\end{array}$ & 868,2 & 527 & 25,3 & 3,7 & 106,8 & 205,4 \\
\hline $\begin{array}{c}\text { Other } \\
\text { businesses }\end{array}$ & 4367,4 & 2800,2 & 92,5 & 18,3 & 303 & 1153,4 \\
\hline $\begin{array}{c}\text { Community- } \\
\text { based farms }\end{array}$ & 15,9 & 0,4 & 0,0 & 0,0 & 8,8 & 6,7 \\
\hline $\begin{array}{c}\text { Cossack } \\
\text { society }\end{array}$ & 95,2 & 66,1 & 0,2 & 0,1 & 6,4 & 22,4 \\
\hline Total land & 114354,4 & 73875,3 & 2213,2 & 380,2 & 9378,4 & 28507,3 \\
\hline
\end{tabular}

The gap between the subjects of the Russian Federation in terms of resource availability is primarily related to the spatial characteristics of the existing territory. The structure of the land Fund of regions differs significantly in the categories of available land, since it is land resources that allow satisfying the interests of society, creating the basis for human activity in the form of capital for profit [16, p. 8]. The spatial characteristics of the region largely depend on the structure of land resources: industrial, energy, transport, communications, radio broadcasting, television, computer science, land for space activities, defense, security, and other special - purpose land; land of specially protected territories and objects, since the efficiency of land resources use depends on their biological soil and landscape-ecological features (table 3 ).

TABLE III. THE SHARE OF UNUSED AGRICULTURAL LAND IN THE REGIONS OF THE CENTRAL FEDERAL DISTRICT OF THE RUSSIAN FEDERATION ACCORDING TO THE ALL-RUSSIAN AGRICULTURAL CENSUSES OF 2006 AND 2016 [1], \%

\begin{tabular}{|c|c|c|c|c|c|c|c|c|}
\hline Regions & \multicolumn{2}{|c|}{$\begin{array}{c}\text { Farms of all } \\
\text { categories }\end{array}$} & \multicolumn{2}{c|}{$\begin{array}{c}\text { Agriculture } \\
\text { organization }\end{array}$} & \multicolumn{2}{c|}{$\begin{array}{c}\text { Farms and } \\
\text { sole } \\
\text { proprietors }\end{array}$} & \multicolumn{2}{c|}{ Households } \\
\cline { 2 - 10 } & $\mathbf{2 0 0 6}$ & $\mathbf{2 0 1 6}$ & $\mathbf{2 0 0 6}$ & $\mathbf{2 0 1 6}$ & $\mathbf{2 0 0 6}$ & $\mathbf{2 0 1 6}$ & $\mathbf{2 0 0 6}$ & $\mathbf{2 0 1 6}$ \\
\hline Belgorod & 10,4 & 4,2 & 10,8 & 3,8 & 6,8 & 5,2 & 10,4 & 7,1 \\
\hline Voronezh & 14,1 & 4,6 & 14,3 & 4,4 & 11,2 & 2,8 & 21,1 & 16,5 \\
\hline Kursk & 21,8 & 5,7 & 24,0 & 5,2 & 8,9 & 1,9 & 14,9 & 23,3 \\
\hline Lipetsk & 13,0 & 5,5 & 11,9 & 5,2 & 183,0 & 1,8 & 20,4 & 21,0 \\
\hline Tambov & 23,5 & 6,6 & 25,8 & 7,0 & 13,7 & 2,5 & 22,1 & 26,1 \\
\hline $\begin{array}{c}\text { Central } \\
\text { Chernozem } \\
\text { region as a } \\
\text { whole }\end{array}$ & 16,7 & 5,3 & 17,4 & 5,1 & 11,8 & 2,7 & 17,9 & 18,4 \\
\hline
\end{tabular}

The table shows that the share of unused land in 2016 compared to 2006 decreased by 3-4 times. As of 01.01.2019, $193,350,7$ thousand hectares, or $87.1 \%$ of all agricultural land available in the Russian Federation, were in use by agricultural organizations and citizens. Land owned by urban and rural settlements, as well as other municipalities, is municipal property $[8$, p. 6]. Information on the availability and distribution of the land Fund of the Russian Federation reflects the intensity and nature of land use (Fig. 5).

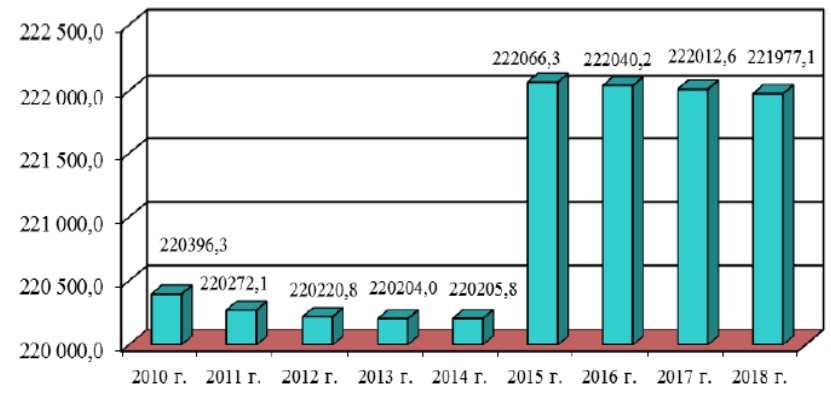

Fig. 5. Dynamics of agricultural land area, thousand ha

Specific positions in the development of land relations serve as the basis for the development of the state in changing conditions and are closely related to the ongoing socioeconomic changes in society. A significant stage in the reform of the procedure for land use and ownership is the maintenance of land and land plots in the unified state register, taking into account their individual characteristics. The land Fund is the most important national asset of the country, its main resource potential, the basis of economic and food security. Russia has a huge amount of land resources. As you know, the most valuable part of agricultural land is agricultural land, including arable land. Russia is among the top five countries in the world in terms of the size of arable land per capita. Agricultural 
organizations used $59.4 \%$ of the area occupied by farmland for production, while citizens used $40.6 \%$ (table 4 ).

Regulation of land relations in the agricultural sector is aimed at targeted effective use of land resources as the basis for organizing agricultural production and building various crops and is largely due to changes in the composition of landowners and land users and their relations to land ownership.

The use of various tools for regulating land relations by Federal and regional authorities contributes to improving the efficiency of land resources use and organization of their reproduction. Active land delineation activities are carried out throughout the Central Chernozem macroregion (Fig. 6).

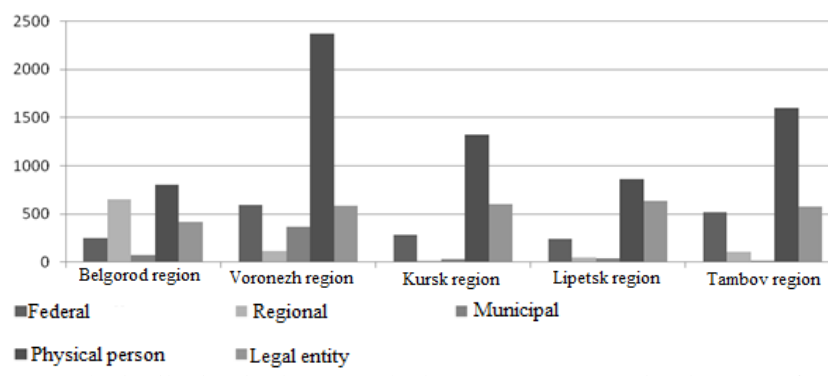

Fig. 6. Land Distribution in the Central Chernozem macroregion by type of ownership as of 01.01.2019, thousand ha [5]

The analysis of the size and structure of agricultural land in the Central Chernozem macroregion shows that the level of agricultural development of the territories fluctuated slightly. The dynamics of such changes can be traced on the example of the Belgorod region (Fig. 7).

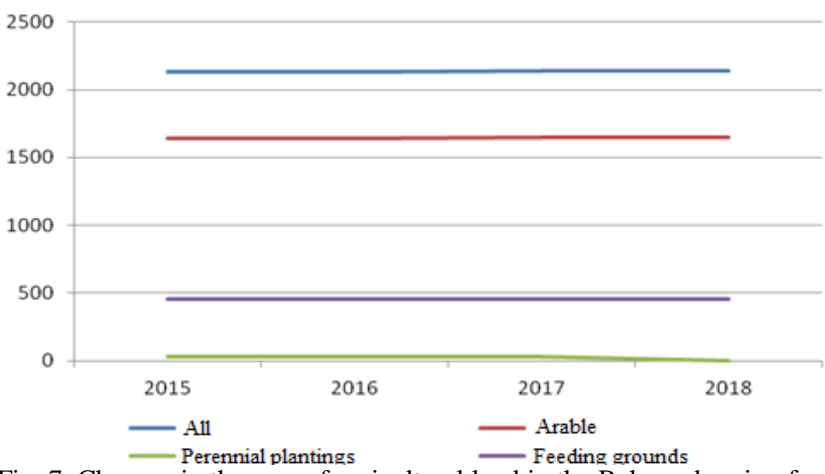

Fig. 7. Changes in the area of agricultural land in the Belgorod region from 2015 to 2018 , thousand hectares

Maximum involvement of agricultural lands in economic turnover and creation of conditions for their effective use is currently a priority direction for the formation and development of the organizational and economic mechanism for the use of land resources. It should be recognized that, despite the long-term practice of land valuation in Russia, the assessment of the market value of agricultural land is associated with great difficulties in methodological and informational terms. The almost complete absence of civilized market relations in the agricultural sector of the economy, the dominance of natural monopolists supplying agriculture with means of production and material resources, on the one hand, together with purchasing organizations, on the other hand, the elimination of the state in the field of regulating pricing for agricultural products puts agricultural producers in unequal partnerships in the market of goods and services and leads to a clear underestimation of both agricultural products and its basis - agricultural land. With the understanding of the need to increase the role of state regulation of agricultural production, direct input into the production and market turnover of agricultural land, the role and importance of an objective assessment of land resources will only increase. In addition to measuring land resources in physical units, it is also necessary to evaluate them in terms of value.

TABLE IV. DISTRIBUTION OF LAND IN THE RUSSIAN FEDERATION BY CATEGORY IN THE CENTRAL FEDERAL DISTRICT (AS OF 01.01.2019), THOUSAND HA

\begin{tabular}{|c|c|c|c|c|c|c|c|c|c|}
\hline $\begin{array}{l}\text { Subject } \\
\text { code }\end{array}$ & $\begin{array}{c}\text { Federal districts and subjects of } \\
\text { the Russian Federation }\end{array}$ & Agricultural land & $\begin{array}{l}\text { Lands of } \\
\text { localities }\end{array}$ & $\begin{array}{l}\text { Industrial } \\
\text { lands and } \\
\text { other } \\
\text { special- } \\
\text { purpose }\end{array}$ & $\begin{array}{c}\text { Lands of } \\
\text { specially } \\
\text { protected } \\
\text { territories } \\
\text { and } \\
\text { objects } \\
\end{array}$ & $\begin{array}{l}\text { The } \\
\text { lands } \\
\text { of the } \\
\text { forest } \\
\text { Fund }\end{array}$ & $\begin{array}{c}\begin{array}{c}\text { Lands } \\
\text { of } \\
\text { water }\end{array} \\
\text { Fund }\end{array}$ & $\begin{array}{l}\text { Reserve } \\
\text { lands }\end{array}$ & $\begin{array}{c}\text { Total land } \\
\text { within } \\
\text { administrative } \\
\text { boundaries }\end{array}$ \\
\hline 1 & 2 & 3 & 4 & 5 & 6 & 7 & 8 & 9 & 10 \\
\hline 31 & Belgorod region & 2088,3 & 346,6 & 38,2 & 2,8 & 228,0 & 2,2 & 7,3 & 2713,4 \\
\hline 32 & Bryansk region & 1976,2 & 193,9 & 39,1 & 12,7 & 1208,8 & 5,1 & 49,9 & 3485,7 \\
\hline 33 & Vladimir region & 983,3 & 214,2 & 132,5 & 0,6 & 1482,3 & 10,9 & 84,6 & 2908,4 \\
\hline 37 & Ivanovo region & 866,0 & 112,0 & 86,0 & 1,3 & 1012,9 & 44,4 & 21,1 & 2143,7 \\
\hline 40 & Kaluga region & 1806,7 & 233,1 & 56,7 & 100,3 & 682,8 & 6,1 & 92,0 & 2977,7 \\
\hline 44 & Kostroma region & 1964,5 & 124,9 & 51,6 & 60,2 & 3655,2 & 71,7 & 93,0 & 6021,1 \\
\hline 46 & Kursk region & 2274,5 & 423,0 & 50,7 & 5,4 & 222,6 & 6,5 & 17,0 & 2999,7 \\
\hline 48 & Lipetsk region & 1918,3 & 244,6 & 41,2 & 14,7 & 178,9 & 6,1 & 0,9 & 2404,7 \\
\hline 50 & Moscow oblast & 1603,0 & 569,7 & 285,8 & 64,7 & 1800,8 & 24,9 & 84,0 & 4432,9 \\
\hline 57 & Orel region & 2035,9 & 197,9 & 23,2 & 35,5 & 169,8 & 1,5 & 1,4 & 2465,2 \\
\hline 62 & Ryazan region & 2483,3 & 235,6 & 61,5 & 103,6 & 975,8 & 30,2 & 70,5 & 3960,5 \\
\hline 67 & Smolensk region & 2219,4 & 290,8 & 72,2 & 114,6 & 1982,0 & 25,4 & 273,5 & 4977,9 \\
\hline 69 & Tver region & 2574,8 & 411,0 & 121,5 & 81,6 & 4832,3 & 174,6 & 224,3 & 8420,1 \\
\hline 71 & Tula region & 1850,6 & 240,4 & 66,0 & 5,7 & 282,7 & 1,8 & 120,7 & 2567,9 \\
\hline 76 & Yaroslavl region & 1225,4 & 203,0 & 51,5 & 54,1 & 1664,0 & 365,2 & 54,5 & 3617,7 \\
\hline 77 & Moscow city & - & 256,1 & - & - & - & - & - & 256,1 \\
\hline
\end{tabular}


In Russia, currently, the assessment of farmland is carried out in accordance with the technical instructions and methodology for cadastral assessment of agricultural land in the subject of the Russian Federation. In the methodology, serious distrust is caused by the definition of differential rental income $\mathrm{D}(\mathrm{B}-\mathrm{PH} \cdot \mathrm{H})$; the value of absolute rental income-Ar (12 rubles/t); the cost recovery coefficient $\mathrm{PH}=$ 1.07 , the value of which does not even compensate for losses from inflation; the choice of setting the capitalization period of land rent $\mathrm{t}=33$ years, which was chosen from two options - 25 and 50 years. But the main disadvantage of the methodology is the departure from setting the price of agricultural products by closing costs, i.e. by the largest costs per unit of land production in agricultural turnover.

One of the tasks of the state land policy is to involve all unused productive agricultural land in economic turnover. From the point of view of economic efficiency of production, the most significant reserves of the agricultural sector are associated with a reduction in the area of unused arable land and deposits.

In the regions of the Central black earth region that are in the zone of intensive agriculture, there is a significant differentiation in the specific weight of unused arable land, and its size underlines the significance of the existing problem. Thus, in all categories of farms in the Voronezh region, the difference between arable land and sown areas was 415.2 thousand hectares $(14.1 \%)$, in the Tambov region - 378.3 thousand hectares $(18.8 \%)$, in the Kursk region 173.6 thousand hectares $(96 \%)$, in the Lipetsk region - 164.6 thousand hectares $(11 \%)$. Only in the Belgorod region this ratio was at the level of $5.1 \%[4$, p. 38].

Land resources management should be based on the operation of a set of objective economic laws, among which we propose to include the law of rational use of land. In accordance with this economic law, the rational use of land resources is determined by the combination of economic, social and environmental effects and ensuring the reproduction of land and its consumer properties. Based on this, when assessing the rationality of land use, it is necessary to study three aspects: economic (obtaining an economic effect by society, land owners and its users and the level of satisfaction of their economic interests); social (the impact on the level of satisfaction of social needs of the population, the level and quality of their life); environmental (maintaining the stability of agroecosystems and agricultural landscapes in order to preserve the ecological balance of the environment).

Within the framework of ensuring the ecological and economic balance of land use, in order to achieve the objectives of strategic regional management of agricultural landscapes, it is necessary to develop comprehensive measures implemented both at the Federal, regional and local levels. In accordance with the concept of "constructing" the ecological frameworks of specific agricultural landscapes and rural territories, it is necessary to implement adaptive intensification of agricultural production, ensuring the rationality of natural and land use in order to achieve optimization of individual agricultural landscapes [8].

The mechanism of land relations regulation, like any other regulatory mechanism, is a set of economic, motivational, organizational and legal tools for purposeful influence of the subject of regulation on the object of regulation. However, at present, the structure and individual components of the land relations regulation mechanism are not yet sufficiently developed, so there is a need to improve this mechanism, taking into account the inclusion of additional organizational and economic instruments in its composition.

Considering the earth as an important natural object, many distinctive features should be noted. First, it refers to the main factors of people's life, is characterized as a source of creating natural working conditions, and refers to the necessary prerequisites for organizing the agricultural production process. Land resources are non-reproducible means of agricultural production that are created directly by nature and in this form can be owned by an economic entity and serve as a material element of real estate. When certain social conditions are created, land participates in commodity circulation, the purpose of which is to obtain added value. In addition, land is the basis of agricultural production, an object for organizing agricultural activities, and a multifunctional tool for obtaining and improving the efficiency of agricultural business. In agricultural production, land resources, being a material condition for its implementation, also serve as an active factor of organization. In addition to the specified conditions in the process of agricultural business, land acts as a subject of labor that is exposed to human influence in order to maintain and develop the process of agricultural production, as well as an instrument of production for cultivating and growing the necessary crops for humans [4, p.39]. Another important feature of land is that it does not relate to the results of human labor, does not have the form of a created product, and therefore does not contain a cost estimate. A completely different opinion exists on agricultural land, since the process of their development, processing, and bringing to a state of readiness for use in agricultural turnover requires not only investments of human labor, but also certain production facilities. In this connection, agricultural land has a consumer value, which is used for economic calculations, is the object of economic transactions, and which may change depending on additional investments in it, as well as on participation in agricultural production.

Thus, in order to improve the improvement of land fertility and reproduction processes, it is necessary to develop proposals on the state impact on the efficiency of land use, organize their valuation taking into account soil fertility, develop a subsidy system and reform the system of taxation of land users.

\section{CONCLUSION}

The study of trends in the use of land resources is based on the example of the Central Chernozem macroregion, which is one of the largest producers of agricultural products in Russia. The analysis of the current state of functioning of land relations in the agricultural sector of Russia shows that the use of land resources is characterized by certain trends. In particular, it is not possible to overcome the trend of reducing the area of farmland and arable land; there are significant fluctuations in the level of use of agricultural land not only in 
districts, but also in the context of regions and regions within the same district; there is a widespread deterioration in the fertility of agricultural land and, above all, arable land; the proportion of eroded and deflated arable land continues to grow, the state of reclaimed land is deteriorating, and degradation processes are increasing, etc.

The study area has a high potential of agricultural land. In the Central Chernozem macroregion, the process of significant withdrawal of agricultural land from economic turnover and the decline in land use efficiency did not lead to radical changes. The results of the 2006 agricultural census show that more than $16.7 \%$ of agricultural land remained unused in farms of all categories, and the results of the 2016 all-Russian agricultural census already show this share at $5.3 \%$. Among the factors that significantly limit the efficiency of agricultural land use are:

- the complexity of tools for state regulation of land relations to the modern needs of the country and international standards;

- underdeveloped land market and low level of state control over the efficiency of its use;

- lack of rational organization of land management ensuring effective use and protection of land;

- lack of reliable information on the qualitative and quantitative characteristics of agricultural land;

- availability of large areas of unused agricultural land and unclaimed land shares;

- lack of information about restrictions and encumbrances of land plots;

- continued decline in soil fertility, increased degradation of productive land, man-made pollution and agricultural land imbalance;

- imperfection of currently used methods for assessing land resources, the main disadvantage of which is the weak accounting of cost when pricing agricultural products at closing costs

- high level of land concentration in integrated agroindustrial structures and others.

In modern conditions, it is necessary to develop and implement cost-effective approaches and models (scenarios) for the development of the agro-industrial complex in macroregions for the next decade, which will provide national conditions and factors for the reproduction of rural socio-territorial communities and the land and natural potential of Russia.

The development of the land relations and land resources management system is one of the state's priority tasks, since it allows increasing the responsibility of landowners and land users for inappropriate, irrational and inefficient use of productive land and creating prerequisites for coordinating the interests of all subjects of land relations. Despite marketoriented economy of modern Russia, that the state should remain a key subject of land administration, protecting the rights of land ownership, transparency of land markets, stimulating the reproduction of productive land and their consumer properties, improved environmental sustainability of agricultural landscapes, creating conditions of growth of efficiency of agricultural production and of rural areas.

\section{ACKNOWLEDGMENT}

The study was carried out within the framework of an intrauniversity grant of the National Research University «BelSU» in accordance with Order No. 826-OD of 14.08.2020, the theme of the project «Smart specialization in the agro-industrial complex of the region: digital transformation and convergent technologies»

\section{REFERENCES}

[1] All-Russian agricultural census of 2016: in 2 vols. 2. Preliminary results of the all-Russian agricultural census of 2016 for the subjects of the Russian Federation. - Moscow: IIC "statistics of Russia", 2017, p. 1110

[2] O.S. Belokrylova, N.N.Kiseleva "Institutional changes in the land market of southern regions", The space economy, №.4-3, 2013. 24.09.2020. URL: https://cyberleninka.ru/article/n/istitutsionalnyeizmeneniya-na-rynke-zemli-yuzhnyh-regionov.

[3] Belgorod region in numbers. 2020: Brief introducti. stat. / Belgorodstat. 2020. 244 p.

[4] N.I. Bukhtoyarov, I.B. Zagaytov, S.I. Yablonovskaya "Problems of regulation of rent relations in agricultural land use", Moscow economic journal, №7, 2019, pp. 38-46.

[5] M.V. Vladyka, O.V. Vaganova, S.A. Kucheryavenko Socio-economic development of the Central Federal district in numbers: monograph, 2016, 80 p.

[6] M.V. Vladyka, D.R. Solntsev "Internal sources of financing for the regional agro-industrial complex in the context of the import substitution policy", Global economy: new format and new guidelines: col. monograph, 2016, pp. 192-202.

[7] I.M. Georgitsa "Features of designing the ecological framework of large territories", Yaroslavl pedagogical Bulletin, №1, 2011. 22.10.2020. URL: https://cyberleninka.ru/article/n/osobennostikonstruirovaniya-ekologicheskogo-karkasa-krupnyh-territoriy.

[8] State (national) report on the state and use of land in the Russian Federation in 2018. Rosreestr 2019. 20.10.2020. URL: https://rosreestr.gov.ru/upload/Doc/16 upr/Госдоклад\%20за\%202018\%20год.pdf.

[9] I.G. Ushachev Collective publication "Methodological approaches to the assessment of the market value of agricultural land from the means of production of the agro-industrial complex and organizations of agricultural science", 2008, pp. 60-61

[10] V.I. Nechaev, G.N. Barsukova, N.R. Saifetdinova "Land management based on the forecast of market development and use of agricultural land in the Russian Federation", Agro-industrial complex: Economics, management, №6, 2016, pp. 43-53.

[11] On the turnover of agricultural land: Federal law № 101-FZ of July 24, 2002. 17.02.2020. URL: https://base.garant.ru/77661081/.

[12] On approval of The rules for determining the amount of payment under the agreement on the establishment of an easement in respect of land plots that are in Federal ownership: Decree of the Government of the Russian Federation № 1461 of December 23, 2014. 08.12.2019. URL: https://base.garant.ru/70828686/

[13] N.E. Pavlenko, D.R. Solntsev "Economic assessment of agricultural land in a planned market economy", Agro-industrial complex: Economics, management, №. 1, 2016, pp. 53-60.

[14] A.V. Petrikov "Land use of various categories of farms based on the results of the all-Russian agricultural census of 2016 and improvement of land policy", Agro-industrial complex: economy, management, №11, 2018, pp. 23-35.

[15] Russia in numbers. Brief statistical collection / Goskomstat of Russia. 2018. 414 p.

[16] V.I. Safonova "Mechanism of economic regulation of land relations in agricultural nature management / V. I. Safonova", Scientific works of the southern branch of the National University of bioresources and 
nature management of Ukraine "Crimean agrotechnological University”. Series: Economic Sciences, № 140, 2011, pp. 3-13.

[17] Data on the availability and distribution of land in the Russian Federation as of 01.01.2017 (in the whole of the Russian Federation). 11.10.2020. URL: https://rosreestr.ru/site/activity/sostoyanie-zemelossii/.

[18] I.A. Trofimov, L.S. Trofimova, E.P. Yakovleva "Conservation and optimization of agricultural landscapes of the Central Chernozem region”, Izvestiya RAS. Geographical series, №1, 2017, pp. 103-109.

[19] S.A. Sharipov "Land relations and land use efficiency in agricultural production", Economics of agricultural and processing enterprises, №4, 2017, pp. 52-56.

[20] Are spatial planning objectives reflected in the evolution of urban landscape patterns? A framework for the evaluation of spatial planning outcomes S Gradinaru, C Ioja, I Patru-Stupariu, A Hersperger Sustainability.11.10.2020. URL: https://www.mdpi.com/2071 1050/9/8/1279.

[21] E.A. Stryabkova, A.M. Kulik, A.N. Kogteva, J.V. Lyshchikova, I.V. Chistnikova "Interregional interaction among the regions of the central black earth makroregion in the Russian Federation", International Journal of Innovative Technology and Exploring Engineering, Vol. 8. № 8, 2019, pp. 3228-3234.

[22] P.R. Krugman, F. Masahisa, J.V. "Anthony The Spatial Economy”: Cities, Regions and International Trade, 1999, 367 p.

[23] J.V. Lyshchikova, E.A. Stryabkova, A.S. Glotova, T.N. Dobrodomova "The "Smart region" concept: the implementation of digital technology", Journal of Advanced Research in Law and Economics. Vol. 10, № 4 (42), 2019, pp. 1338-1345. 